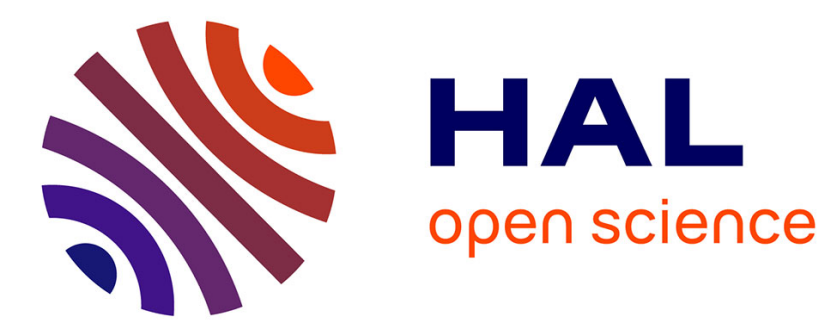

\title{
The Thangmi verbal agreement system and the Kiranti connection
}

Mark Turin

\section{To cite this version:}

Mark Turin. The Thangmi verbal agreement system and the Kiranti connection. Bulletin of the School of Oriental and African Studies, 1998, 61 (3), pp.476-491. 10.1017/S0041977X00019303. halshs-03083388

\section{HAL Id: halshs-03083388 \\ https://shs.hal.science/halshs-03083388}

Submitted on 27 Jan 2021

HAL is a multi-disciplinary open access archive for the deposit and dissemination of scientific research documents, whether they are published or not. The documents may come from teaching and research institutions in France or abroad, or from public or private research centers.
L'archive ouverte pluridisciplinaire HAL, est destinée au dépôt et à la diffusion de documents scientifiques de niveau recherche, publiés ou non, émanant des établissements d'enseignement et de recherche français ou étrangers, des laboratoires publics ou privés. 


\title{
The Thangmi verbal agreement system and the Kiranti connection
}

\author{
MARK TURIN \\ Himalayan Languages Project, Leiden University
}

\section{Introduction}

Thangmi is a Tibeto-Burman language spoken in central-eastern Nepal and north-eastern India. The majority of Thangmi speakers live in Nepal and still inhabit their traditional homeland of Dolakhā district. There are ethnic Thangmi in many of the other districts of the kingdom, especially in the neighbouring districts of Sindhupālcok, Sindhulī and Rāmechāp. The Thangmi population in India is largely concentrated in Darjeeling and is the product of an emigration earlier this century.

Hodgson recorded the name of the Thangmi language as 'Thámi'. However, the correct English name for this people and their language should be Thangmi. The details are as follows. The Thangmi call themselves Thanmi, but in elevated ritual language the shamans use the term Thani. The Nepali designation for this group, on the other hand, is Thāmī, whence Hodgson's version of the name derives. In the same way as various Kiranti peoples such as the Sampang, Kulung, Bantawa and so forth use the collective surname ' Ràì' in lieu of their proper clan names, so too the Thangmi people often use the collective Nepali ethnonym 'Thāmī' as a surname, which also happens to be the way the name appears on official Nepalese census reports and statistics. The name Thangmi has two possible etymologies, one being पर' \$ి' (than-mi) 'people of the steppe', the other being the more disparaging but potentially more plausible มูฉ' \$े (mthah-mi) 'barbarians'. The syllable-final consonant $R$ in the first syllable of the latter Tibetan term could yield a velar nasal in the given context if, in this word, the letter does not serve just as an orthographic device. The prefixed letter $\approx$ is, of course, not sounded in modern Tibetan.

Today there are around 50,000 ethnic Thangmi, excluding the unsurveyed Darjeeling population. Thangmi, which is still widely spoken, was first studied by Sten Konow for the Linguistic Survey of India (1909) and then classified as an 'Eastern Pronominalized' language alongside Barām. Hodgson recorded a word list of this latter language under the name 'Bhrámú', but we now know on the basis of van Driem's investigations that this language is correctly known as Barām. Konow's linguistic sketch, which appeared in Grierson's compilation, provided a grammatical outline of Thangmi along with a list of some 200 words and short phrases. In 1966, Shafer added his support to the earlier argument for Thangmi and Barām relatedness by positing nine lexical similarities shared by the two languages. Three of these may now be discounted as they are widely attested in Tibeto-Burman languages, leaving only six words supporting a link between Thangmi and Barām. Shafer (1966: 128) suggests that the following lexical correspondences show a clear link between Barām and Thangmi.

$\begin{array}{lll}\text { English } & \text { Bhrámú } & \text { Thami } \\ \text { one } & \text { dé } & \text { di-ware } \\ \text { two } & \text { ni } & \text { nis } \\ \text { sun } & \text { u-ní } & \text { u-ni } \\ \text { moon } & \text { chala-wani } & \text { tśala } \\ \text { house } & \text { nam } & \text { nem }\end{array}$




$\begin{array}{lll}\text { tooth } & \text { s-wá } & \text { su-wa } \\ \text { eat } & \text { chá } & \text { tśiya } \\ \text { ear } & \text { ká-pá } & \text { ku-lna } \\ \text { head } & \text { ká-pá } & \text { ka-pu }\end{array}$

The Barām and Thangmi words for 'one' seem to derive from the Proto-

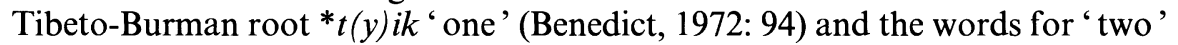
in both languages are also reflexes of the widely-attested Proto-Tibeto-Burman root * $g$-ni-s (Benedict, 1972: 16). Consequently, the words 'one' and 'two' only serve to indicate the already indisputable Tibeto-Burman nature of Barām and Thangmi, rather than indicating any special relationship between the two languages. Likewise, where Shafer suggests that Barām ká-pá 'head' and Thangmi $k a-p u$ 'head' are unusual forms, he may have been unaware of the Nepali form kapāl 'head' and the Kusuvār form ká-pá 'head'. Even in the little known language of Thochú, the form kapat 'head' has been attested. It seems more plausible to suggest that the words for 'head' in both languages are Indo-Aryan loans rather than to argue for a separate lexicogenesis. The remaining six words on Shafer's list, however, do seem to support a link between Barām and Thangmi. For a full discussion of the evidence and a careful analysis of the arguments involved, see Loeffen (1995).

Despite the scanty empirical basis for the classification, it appears from more recent research (van Driem, forthcoming) that their suspicions may indeed have been correct. While the Barām system of verbal agreement has all but decayed, the verbal morphology of Thangmi is complex and reminiscent of the Kiranti model, the discussion of which has been largely acted out and developed on the pages of this journal. Not only does the completeness of the Thangmi verbal paradigm give us an insight into the degenerated Barām agreement system, but it also seems to provide a fascinating link between the canonical Kiranti model of verbal morphology and the simpler, although clearly related, Dolakhā Newar agreement system.

Kiranti languages are typically characterized by verbal agreement systems which even by Tibeto-Burman standards may be seen as complex. Conjugations of Kiranti verbs often have two or three prefixal slots and up to eight suffixal slots, and person-number agreement is frequently encoded through portmanteau morphemes or even tensed portmanteau morphemes, especially when involving a first person singular actant (van Driem, 1990). It is generally accepted that the positing of slots facilitates the comparison of cognate verbal morphologies, as the order of affixal morphemes in Tibeto-Burman verbal conjugations reflects a non-random sequencing as well as an 'ancient element order' in the proto-language (van Driem, 1993a: 293, Rutgers, 1993). An inflected simplex form in Thangmi consists of a verb stem to which affixes are attached, indicating tense and showing person and number agreement with one or both of the actants of the verb. In the Thangmi context, an agent is defined as the most agentive actant of a transitive verb while a patient is defined as the least agentive actant of a transitive verb. A transitive verb agrees with the agent or patient, and often both. A subject is defined as the actant with which an intransitive or reflexive verb agrees. Furthermore, singular number is one, and plural number is two or more. Unlike many of the Kiranti languages, Thangmi does not differentiate for dual number, nor does it exhibit an inclusive-exclusive distinction.

In the present study, I offer a synchronic morphemic analysis of the Thangmi verb and then make some diachronic observations where I compare the verbal morphology of Thangmi with the Proto-Kiranti model. In 
accordance with accepted convention, morphemes and allomorphs are given between pointed brackets, phonemes between slanted brackets, and allophones and phonetic transcriptions between square brackets. The Thangmi data were collected by the author during field work in Nepal in the early part of $1997 .^{1}$

\section{Analysis of the Thangmi verb}

In this section I shall proceed to give a rigorous morphemic analysis of the finite verb in the Thangmi language and appraise its significance in the historical comparative context. The following discussion therefore presupposes some familiarity with the synchronic morphological analysis of conjugational systems in general, as well as familiarity with the historical comparative treatment of Tibeto-Burman verbal morphology in particular. I have limited the morphological analysis to the bare essentials, employing only tried and tested analytical notions, such as functional positions or slots, prefixes, suffixes, morphemes, allomorphs, portmanteau morphemes and easily demonstrable morphophonological rules. A slot is no more than the relative linear position of a morpheme in a sequence of morphemes, and the other notions are likewise used here in their conventional senses. Readers who wish to dispense with the detailed synchronic argumentation should feel free to move on to the diachronic ramifications of this analysis as presented in section 3 .

Thangmi distinguishes only six pronominal categories: three persons and two numbers. They are shown below in Table $1 .{ }^{2}$ Personal pronouns may be used in conjunction with the corresponding verb forms for emphasis, but are not strictly necessary.

TABLE 1: Thangmi personal pronouns

$\begin{array}{lll}\text { gai } & \text { I } & 1 \mathrm{~s} . \\ n i & \text { we } & 1 \mathrm{pl} . \\ \text { nay } & \text { you } & 2 \mathrm{~s} . \\ \text { nin } & \text { you } & 2 \mathrm{pl} . \\ \text { to } & \text { he, she, it } & 3 \mathrm{~s} . \\ \text { tobay } & \text { they } & 3 \mathrm{pl} .\end{array}$

A segmental morphemic analysis of the Thangmi conjugational endings requires positing seven distinct functional positions or slots in the affixal string of a Thangmi verb. This affixal string can be subdivided into one prefixal slot and six suffixal slots to accommodate the complete Thangmi paradigm. Each

\footnotetext{
${ }^{1}$ A shorter version of this paper was given at the third Himalayan Languages Symposium at University of California, Santa Barbara, 18-20 July 1997. For financial support, I am grateful to the School of Asian, African, and Amerindian Studies (CNWS) of Leiden University, and for advice and continued interest in my work, I am much obliged to George van Driem and Frederik Kortlandt. 
slot may contain one or more morphemes which have some semantic features in common. In some cases, a morpheme cannot be assigned to a specific suffixal slot because it occupies a position which can only be described as anterior to certain suffixes and posterior to others in the affixal chain. In these situations I have assigned, albeit tentatively, the morpheme to a suffixal slot on the basis of semantic and pragmatic considerations. These 'free-floating' morphemes are the following. Both the first personal plural patient or subject morpheme $<-i \sim-P i>$ (1pl.PS) and the first person plural agent morpheme $<-w a>$ (1pl.A) have been placed in suffixal slot 2 , the number and person morpheme slot, although both suffixes could occupy an affixal position anywhere after the reflexive morpheme $<-\int i>(\mathrm{REF})$, which occupies suffixal slot 1 , and before the tense and tensed portmanteau morphemes of suffixal slot 6 . The portmanteau morpheme $\langle-n\rangle(1 \mathrm{~s} . \rightarrow 3)$ could occupy either suffixal slot 4 or 5 , as it appears after the third person patient morpheme $<-u>(3 \mathrm{P})$ but before the tensed portmanteau morpheme $<-u \eta>(1 \mathrm{~s} . \rightarrow 3 / \mathrm{PT})$. Because of the shared feature of first person singular involvement, the portmanteau morpheme $<-n\rangle \quad(1 \mathrm{~s} . \rightarrow 3)$ was placed alongside the first person singular morpheme $<-n a>$ (1s.) in suffixal slot 5 , which can be defined as the first person singular morpheme slot.

Like the portmanteau morpheme $<-n>(1 \mathrm{~s} . \rightarrow 3)$, the tensed portmanteau morpheme $<-u \eta>(1 \mathrm{~s} . \rightarrow 3 / \mathrm{PT})$ occurs only in the transitive scenario between a first person agent and a third person patient, and then always after the portmanteau morpheme $\langle-n\rangle(1 \mathrm{~s} . \rightarrow 3)$. The functional position of the suffix $<-u \eta\rangle$ depends on which suffixal slot the morpheme $<-n\rangle(1 \mathrm{~s} . \rightarrow 3)$ is assigned to. As outlined above, for reasons of semantic consistency the portmanteau morpheme $\langle-n\rangle$ has been assigned to the fifth functional position, and so concomitantly the associated suffix $\langle-u \eta\rangle$ must occupy the following functional position, which is suffixal slot 6 . Finally, the tensed portmanteau morpheme $<n \boldsymbol{}>(3 \rightarrow 3 / \mathrm{PT})$ could occupy a position between suffixal slots 4 and 6 , since the morpheme follows the third person patient morpheme $<-u>$ (3P) of suffixal slot 3 . Semantic considerations being such that all other morphemes indexing tense in Thangmi occupy the final functional position, suffixal slot 6 , I decided to place the tensed portmanteau morpheme $<-n s>(3 \rightarrow 3 / \mathrm{PT})$ in this final position, the so-called tense and tensed portmanteau slot. An overview of the Thangmi verbal agreement suffixes and their functional positions is provided in the chart in table 2 .

TABLE 2: Relative position of morphemes in the affixal string of the Thangmi verb

\begin{tabular}{|c|c|c|c|c|c|c|c|}
\hline \multirow[t]{3}{*}{$\mathrm{pf} x$} & stem & sf.1 & sf. 2 & sf. 3 & sf. 4 & sf. 5 & sf.6 \\
\hline & & & $\begin{array}{c}\varnothing \\
\text { s. } A S\end{array}$ & & & & $\begin{array}{c}d u \\
N P T\end{array}$ \\
\hline & & & $\begin{array}{c}\text { yon } \\
\text { pl.AS }\end{array}$ & & & $\begin{array}{l}\text { ya } \\
\text { ls. }\end{array}$ & $\begin{array}{c}n \\
P T\end{array}$ \\
\hline \multirow[t]{3}{*}{$\begin{array}{c}m a \\
\text { NEG }\end{array}$} & $\Sigma$ & $\underset{\mathrm{REF}}{\int i}$ & $\begin{array}{l}n i \sim n \\
2 \mathrm{pl} .\end{array}$ & $\begin{array}{c}u \\
3 \mathrm{P}\end{array}$ & $\begin{array}{l}n a \\
2 \mathrm{~s} .\end{array}$ & & $\begin{array}{c}a n \\
\text { 3S/PT }\end{array}$ \\
\hline & & & $\begin{array}{l}i \sim P i \\
1 p l . P S\end{array}$ & & & $\begin{array}{c}n \\
1 s . \rightarrow 3\end{array}$ & $\underset{1 s . \rightarrow 3 / P T}{u \eta}$ \\
\hline & & & $\begin{array}{c}w a \\
1 \mathrm{pl} . \mathrm{A}\end{array}$ & & & & $\stackrel{\substack{n o \\
3 \rightarrow 3 / \mathrm{PT}}}{ }$ \\
\hline
\end{tabular}


The prefixal slot is the functional position for the negative morpheme $<m a->(\mathrm{NEG})$. Following the stem, suffixal slot 1 is the reflexive slot while person and number markers occur in suffixal slot 2 . The third person patient morpheme occurs in slot 3 and the second person singular morpheme in slot 4. Suffixal slot 5 is the functional position for first person singular morphemes and suffixal slot 6 is the position for tense and tensed portmanteau morphemes.

Certain morphemes index for agent of a transitive verb and subject of an intransitive verb as opposed to patient, following an accusative pattern, such as the plural agent or subject marker $<-y o \eta>$ for non-first person (pl.AS) and the zero morpheme indexing singular agent or subject for non-first person (s.AS). However, the first person plural patient or subject morpheme $<-i \sim-P i>$ (1pl.PS) specifies patient and subject as opposed to first person plural agent-which is indexed by $1 \mathrm{pl}$.A <-wa $>$-reflecting an ergative pattern.

The negative morpheme $\langle m a-\rangle$ (NEG) is the only verbal prefix and occurs in all negative simplex forms in both preterite and non-preterite tenses of transitive, intransitive and reflexive verbs. In all non-preterite negative forms, the negative morpheme $\langle m a->$ appears solely with the verbal stem $(\Sigma)$, and all the person, number and tense suffixes which are present in the affirmative forms do not appear. Since these forms do not show agreement for person and number, personal pronouns are used more often to disambiguate the identity of the verbal actants, as seen below. In the negated preterite, however, all the verbal agreement suffixes are present.

$$
\begin{array}{ll}
\text { gai } & y a-n a-d u \\
\text { I } & \text { go-1s.-NPT } \\
\text { 'I go/I am going.' }
\end{array}
$$

(2) nay ma-ca

you NEG-eat

'You don't eat/you are not eating.'

(3) tobay ma-ya-yon-an

they NEG-go-pl.AS-3S/PT

'They didn't go/they haven't gone.'

The reflexive morpheme $<-f i>$ (REF) occurs in reflexive forms, where it indexes a reflexive relationship. This morpheme is a suffixal slot 1 filler and is affixed immediately to the stem before any of the person and number suffixes.

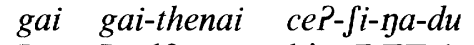

$$
\begin{aligned}
& \text { I I-self bite-REF-1s.-NPT } \\
& \text { 'I bite myself.' }
\end{aligned}
$$

The second functional position in the Thangmi affixal string can be occupied by five morphemes semantically unified only in as much as they all mark number and person and all follow the reflexive morpheme $<-f i>(\mathrm{REF})$ and precede the third person patient marker $<-u>(3 \mathrm{P})$, thereby occupying suffixal slot 2.

The number marker <-yon> (pl.AS) denotes a second or third person plural agent in a transitive verb and a third person plural subject in an intransitive or reflexive verb, reflecting an accusative pattern as mentioned above. Other fillers of suffixal slot 2 include the zero morpheme (s.AS), which, following the accusative pattern, marks a second or third person singular agent in a transitive verb and a third person singular subject in an intransitive or reflexive verb. Neither of these two number morphemes mark number of subject in the second person of intransitive or reflexive verbs because the 
involvement of a second person singular or plural subject is marked by $<-n a>(2 \mathrm{~s}$.) and <-ni> (2pl.), respectively. In the Thangmi verbal paradigm, number of first person is denoted by three distinct suffixes: The ending $<-\eta a>$ marks for a first person singular actant (1s.), the ending $<-i \sim-P i>$ marks for first person plural patient or subject (lpl.PS), and the ending $<-w a>$ indexes first person plural agent (1pl.A).

Another suffixal slot 2 filler is the second person plural actant morpheme $<-n i\rangle$ (2pl.), which has a regular allomorph $\langle-n\rangle$ before a vowel. The second person plural actant morpheme $<-n i \sim-n>$ (2pl.) occurs in all transitive, intransitive and reflexive scenarios which encode specifically the involvement of a second person plural actant.

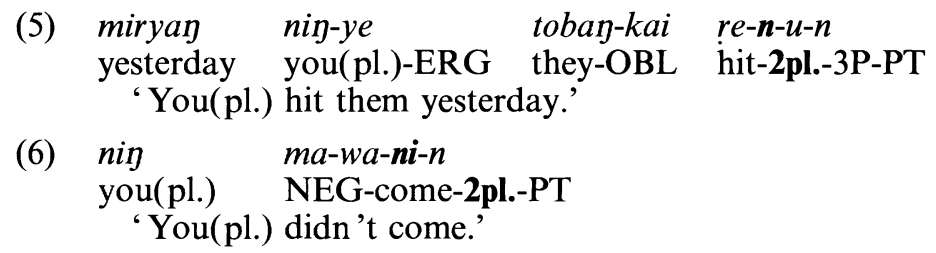

The first person plural patient or subject morpheme $<-i>$ (1pl.PS), which has a regular allomorph $<-$ Pi $>$ after a vowel, is likewise a suffixal slot 2 filler. The morpheme occurs in all transitive relationships involving a first person plural patient and all intransitive or reflexive scenarios involving a first person plural subject.

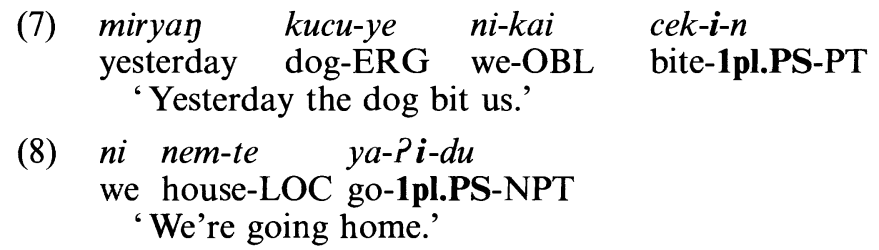

The final suffixal slot 2 filler is the first person plural agent morpheme $<-w a>(1 \mathrm{pl} . \mathrm{A})$, which occurs in all transitive scenarios involving a first person agent. It occurs after the reflexive morpheme $<-f i>(\mathrm{REF})$ and before the final functional position, suffixal slot 6 . As outlined above, I have assigned it on semantic grounds to the second functional position, suffixal slot 2, alongside the other number and plural markers.

Suffixal slot 3 is reserved for the third person patient morpheme $<-u>$ (3P) which occupies a position after the number and person morphemes of suffixal slot 2 and before the second person singular marker $<-n a>(2 \mathrm{~s}$.) of suffixal slot 4 . The third person patient morpheme $<-u>(3 \mathrm{P})$ occurs in all transitive strings involving a third person patient, except in $3 \mathrm{pl} . \rightarrow 3$ forms, where the transitive relationship between a third person plural agent and a third person patient is marked by the specific portmanteau $<-n \vartheta>(3 \rightarrow 3 / \mathrm{PT})$ in the preterite tense, while in the corresponding non-preterite forms the involvement of a third person patient is implicit and left unmarked. In $3 \mathrm{~s} . \rightarrow 3$ forms in the preterite tense, both the third person patient morpheme $<-u\rangle$ (3P) and the tensed portmanteau $<-n$ s $>(3 \rightarrow 3 / \mathrm{PT})$ co-occur, cf. (15).

$$
\begin{array}{lll}
\text { kucu-pali-ye } & \text { huca-pali-kai } & \text { ceP-yon-no } \\
\text { dog-pl.-ERG } & \text { child-pl.-OBL } & \text { bite-pl.AS-3 } \rightarrow \text { 3/PT }
\end{array}
$$

'The dogs bit the children.'

$$
\begin{array}{llc}
\begin{array}{l}
\text { bubu-pali-ye } \\
\text { older.brother-pl.-ERG }
\end{array} \text { humi-pali-kai } & \text { younger.sister-pl.-OBL } & \text { re-yon-du } \\
\text { 'The older brothers hit their younger sisters.' (non-preterite tense) }
\end{array}
$$


The fourth functional position, sf.4, in the Thangmi affixal string houses the second person singular actant marker $<-n a>(2 \mathrm{~s}$.), which follows the third person patient marker $<-u>(3 \mathrm{P})$ of suffixal slot 3 and precedes the morphemes in suffixal slot 5 indicating first person singular involvement, $<-\eta a>$ (1s.) and $<-n>(1 \mathrm{~s} . \rightarrow 3)$. Since the second person singular suffix $<-n a>$ specifically indexes for the involvement of a second person singular actant in all transitive, intransitive and reflexive conjugations, the suffix is not present when the person of the agent of a transitive relationship is unspecified, e.g. in the Thangmi s. $\rightarrow 1$ s. form ' he/she/you(s.) hits/hit me'. In Thangmi, this transitive relationship is not specific to the person of the agent - only singular number is explicitly marked - and number of agent is all that is marked by the singular agent or subject zero morpheme (s.AS).

$$
\begin{array}{lll}
n a \eta-y e & g a i-k a i & r e-\varnothing-\eta a-d u \\
\text { you(s.)-ERG } & \text { I-OBL } & \text { hit-s.AS-1s.-NPT } \\
\text { 'You(s.) hit me.' } &
\end{array}
$$

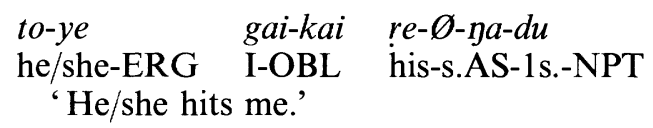

The fifth functional position in the Thangmi affixal string, suffixal slot 5 , is occupied by first person singular role markers. The first person singular suffix $<-\eta \eta a>$ (1s.) marks involvement of a first person singular actant in all transitive, intransitive and reflexive conjugations except in $1 \mathrm{s.} \rightarrow 3$ forms, where the portmanteau morpheme $<-n>(1 \mathrm{~s} . \rightarrow 3)$ specifically indexes a transitive relationship between a first person singular agent and a third person patient. The first person singular morpheme $<-n a\rangle$ (1s.) occurs after the second person singular morpheme $<-n a>(2 \mathrm{~s}$.) and before the final functional position, suffixal slot 6 . The portmanteau morpheme $<-n>(1 \mathrm{~s} . \rightarrow 3)$ also occupies a functional position before the tense and tensed portmanteau morphemes of suffixal slot 6 and after the third person patient marker $<-u>(3 \mathrm{P})$ in suffixal slot 3 . On the basis of semantic and pragmatic considerations, the portmanteau $<-n>(1 \mathrm{~s} . \rightarrow 3)$ has been assigned to suffixal slot 5 .

\section{(13) ba?te gai-ye kucu-kai cek-u-n-du tomorrow I-ERG dog-OBL bite-3P-1s. $\rightarrow$ 3-NPT \\ 'Tomorrow I'm going to bite the dog.'}

The sixth and final slot in a Thangmi affixal string is occupied by tense and tensed portmanteau morphemes. All of these morphemes follow the first person singular suffix $<-n a>$ (1s.) except for the tensed portmanteau $<-n \supset>$ $(3 \rightarrow 3 / \mathrm{PT})$, which follows the third person patient morpheme $<-u>(3 \mathrm{P})$ of suffixal slot 3 and has been assigned the to the final functional position for reasons outlined above. The ending $<-d u>$ marks non-preterite tense (NPT) in each and every case, and the suffix $<-n>$ marks preterite tense (PT) unless there is a more specific tensed portmanteau which marks preterite tense as well as person and/or number of actant. The three tensed portmanteaus are: the suffix $<-a n>$, which marks a third person subject of an intransitive verb in preterite time $(3 \mathrm{~S} / \mathrm{PT})$, the morpheme $<-n s\rangle$, which marks a transitive relationship between a third person agent and a third person patient in preterite time $(3 \rightarrow 3 / \mathrm{PT})$, and finally the ending $\langle-u \eta\rangle$, which marks a transitive relationship between a first person singular agent and a third person patient in preterite time $(1 \mathrm{~s}$. $\rightarrow 3 / \mathrm{PT})$. As can be seen from the following examples, the first person agent and third person agent transitive strings are elaborate and sometimes tautological in their morphological structure. 


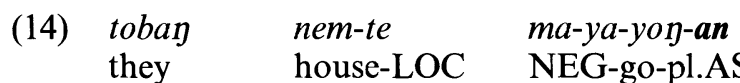

'They didn't go home.'

(15) miryan ama-ye huca-pali-kai re-Ø-u-no

yesterday mother-ERG child-pl.-OBL hit-s.AS-3P-3 $\rightarrow$ 3/PT

'Yesterday mother hit the children.'

(16) miryay gai-ye kucu-kai cek-u-n-un

yesterday I-ERG dog-OBL bite-3P-1s. $\rightarrow$ 3-1s. $\rightarrow$ 3/PT

'Yesterday I bit the dog.'

The possible morpheme strings which occur in the simplicia of intransitive and transitive verbs are illustrated below. Under each agreement heading, the four morpheme strings represent the non-preterite, the non-preterite negative, the preterite and the preterite negative simplex, respectively. The negative forms are listed below the corresponding affirmative forms. Full morphemic analyses are provided of the intransitive verb $y a-s a$ 'to go' and the transitive verb ce?-sa 'to bite'. The morphophonological alternation of the verb stem forms is highly regular and will not be further elaborated on here.

TABLE 3: Possible morpheme strings - intransitive paradigm

\begin{tabular}{|c|c|c|}
\hline & Non-preterite & Preterite \\
\hline \multirow[t]{2}{*}{ 1s. } & $\begin{array}{l}y a-y a-d u \\
\Sigma-1 \text { s.-NPT }\end{array}$ & $\begin{array}{l}y a-\eta y a-n \\
\Sigma-1 \mathrm{~s} . \mathrm{PT}\end{array}$ \\
\hline & $\begin{array}{l}m a-y a \\
\text { NEG- } \Sigma\end{array}$ & $\begin{array}{l}m a-y a-\eta n a-n \\
\text { NEG- } \Sigma-1 \mathrm{~s} .-\mathrm{PT}\end{array}$ \\
\hline \multirow[t]{2}{*}{$1 \mathrm{pl}$. } & $\begin{array}{l}y a-P i-d u \\
\Sigma-1 \text { pl.PS-NPT }\end{array}$ & $\begin{array}{l}y a-P i-n \\
\Sigma-1 \text { pl.PS-PT }\end{array}$ \\
\hline & $\begin{array}{l}m a-y a \\
\text { NEG- } \Sigma\end{array}$ & $\begin{array}{l}m a-y a-P i-n \\
\text { NEG- } \Sigma-1 \text { pl.PS-PT }\end{array}$ \\
\hline \multirow[t]{2}{*}{$2 s$} & $\begin{array}{l}y a-n a-d u \\
\Sigma-2 \text { s.-NPT }\end{array}$ & $\begin{array}{l}y a-n a-n \\
\sum-2 \mathrm{~s} . \mathrm{PT}\end{array}$ \\
\hline & $\begin{array}{l}m a-y a \\
\text { NEG- } \Sigma\end{array}$ & $\begin{array}{l}m a-y a-n a-n \\
\text { NEG- } \sum-2 \text { s.-PT }\end{array}$ \\
\hline \multirow[t]{2}{*}{$2 \mathrm{pl}}$. & $\begin{array}{l}y a-n i-d u \\
\Sigma-2 \text { pl.-NPT }\end{array}$ & $\begin{array}{l}y a-n i-n \\
\Sigma-2 \text { pl.-PT }\end{array}$ \\
\hline & $\begin{array}{l}m a-y a \\
\text { NEG- } \Sigma\end{array}$ & $\begin{array}{l}m a-y a-n i-n \\
\text { NEG- } \Sigma-2 \text { pl.-PT }\end{array}$ \\
\hline \multirow[t]{2}{*}{$3 \mathrm{~s}$} & $\begin{array}{l}y a-\emptyset-d u \\
\Sigma \text {-s.AS-NPT }\end{array}$ & $\begin{array}{l}\text { yah-Ø-an } \\
\Sigma \text {-s.AS-3S/PT }\end{array}$ \\
\hline & $\begin{array}{l}m a-y a \\
\text { NEG- } \Sigma\end{array}$ & $\begin{array}{l}\text { ma-yah-Ø-an } \\
\text { NEG- } \Sigma \text {-s.AS-3S/PT }\end{array}$ \\
\hline \multirow[t]{2}{*}{$3 \mathrm{pl}$. } & $\begin{array}{l}\text { ya-yon-du } \\
\Sigma \text {-pl.AS-NPT }\end{array}$ & $\begin{array}{l}\text { ya-yon-an } \\
\Sigma \text {-pl.AS-3S/PT }\end{array}$ \\
\hline & $\begin{array}{l}m a-y a \\
\text { NEG- } \Sigma\end{array}$ & $\begin{array}{l}\text { ma-ya-yon-an } \\
\text { NEG- } \sum \text {-pl.AS-3S/PT }\end{array}$ \\
\hline
\end{tabular}


TABLE 4: Possible morpheme strings - transitive paradigm

\begin{tabular}{|c|c|c|}
\hline & Non-preterite & Preterite \\
\hline \multirow[t]{2}{*}{$1 \mathrm{~s} . \rightarrow 2 \mathrm{~s}$} & $\begin{array}{l}c e \text { 2-na-na-du } \\
\Sigma-2 \text { s.-1s.-NPT }\end{array}$ & $\begin{array}{l}\text { ceP-na-na-n } \\
\Sigma-2 \text { s.-1s.-PT }\end{array}$ \\
\hline & $\begin{array}{l}m a-c e ? \\
\text { NEG- } \Sigma\end{array}$ & $\begin{array}{l}\text { ma-ceP-na-na-n } \\
\text { NEG- } \Sigma-2 \text { s.-1s.-PT }\end{array}$ \\
\hline \multirow[t]{2}{*}{ 1s. $\rightarrow 2$ pl. } & $\begin{array}{l}c e P-n i-n a-d u \\
\Sigma-2 \text { pl.-1s.-NPT }\end{array}$ & $\begin{array}{l}c e \text { 2-ni-na-n } \\
\Sigma-2 \text { pl.-1s.-PT }\end{array}$ \\
\hline & $\begin{array}{l}\text { ma-ce? } \\
\text { NEG- } \Sigma\end{array}$ & $\begin{array}{l}\text { ma-ceP-ni-na-n } \\
\text { NEG- } \Sigma-2 \text { pl.-1s.-PT }\end{array}$ \\
\hline \multirow[t]{2}{*}{ 1s. $\rightarrow 3$} & $\begin{array}{l}c e k-u-n-d u \\
\Sigma-3 \mathrm{P}-1 \mathrm{~s} . \rightarrow 3-\mathrm{NPT}\end{array}$ & $\begin{array}{l}c e k-u-n-u \eta \\
\sum-3 \mathrm{P}-1 \mathrm{~s} . \rightarrow 3-1 \mathrm{~s} . \rightarrow 3 / \mathrm{PT}\end{array}$ \\
\hline & $\begin{array}{l}\text { ma-ce? } \\
\text { NEG- } \Sigma\end{array}$ & $\begin{array}{l}\text { ma-cek-u-n-un } \\
\text { NEG- } \Sigma-3 \mathrm{P}-1 \mathrm{~s} . \rightarrow 3-1 \mathrm{~s} . \rightarrow 3 / \mathrm{PT}\end{array}$ \\
\hline \multirow[t]{2}{*}{$1 \mathrm{pl} . \rightarrow 2 / 3$} & $\begin{array}{l}c e P-w a-d u \\
\Sigma-1 \text { pl.A-NPT }\end{array}$ & $\begin{array}{l}c e \text { P-wa-n } \\
\Sigma-1 \mathrm{pl} . \mathrm{A}-\mathrm{PT}\end{array}$ \\
\hline & $\begin{array}{l}\text { ma-ce? } \\
\text { NEG- } \Sigma\end{array}$ & $\begin{array}{l}m a-c e P-w a-n \\
\text { NEG- } \Sigma-1 \text { pl.A-PT }\end{array}$ \\
\hline \multirow[t]{2}{*}{ s. $\rightarrow 1 \mathrm{~s}$} & $\begin{array}{l}c e P-\varnothing-\eta a-d u \\
\Sigma \text {-s.AS-1s.-NPT }\end{array}$ & $\begin{array}{l}c e P-\emptyset-\eta a-n \\
\Sigma \text {-s.AS-1s.-PT }\end{array}$ \\
\hline & $\begin{array}{l}\text { ma-ce? } \\
\text { NEG- } \Sigma\end{array}$ & $\begin{array}{l}\text { ma-ceP-Ø-pa-n } \\
\text { NEG- } \Sigma-\mathrm{s} . A \mathrm{~A}-1 \mathrm{~s} . \mathrm{PT}\end{array}$ \\
\hline \multirow[t]{2}{*}{ pl. $\rightarrow 1 \mathrm{~s}$} & $\begin{array}{l}\text { ceP-yon-na-du } \\
\Sigma \text {-pl.AS-1s.-NPT }\end{array}$ & $\begin{array}{l}\text { ceP-yon-na-n } \\
\Sigma \text {-pl.AS-1s.-PT }\end{array}$ \\
\hline & $\begin{array}{l}\text { ma-ce? } \\
\text { NEG- } \Sigma\end{array}$ & $\begin{array}{l}\text { ma-ceP-yon-пa-n } \\
\text { NEG- } \Sigma \text {-pl.AS-1s.-PT }\end{array}$ \\
\hline \multirow[t]{2}{*}{$2 / 3 \rightarrow 1 \mathrm{pl}$} & $\begin{array}{l}c e k-i-d u \\
\sum-1 \mathrm{pl} \text { l.PS-NPT }\end{array}$ & $\begin{array}{l}c e k-i-n \\
\Sigma-1 \text { pl.PS-PT }\end{array}$ \\
\hline & $\begin{array}{l}m a-c e ? \\
\text { NEG- } \Sigma\end{array}$ & $\begin{array}{l}m a-c e k-i-n \\
\text { NEG- } \Sigma-1 \text { pl.PS-PT }\end{array}$ \\
\hline \multirow[t]{2}{*}{$2 \mathrm{~s} . \rightarrow 3$} & $\begin{array}{l}c e k-u-n a-d u \\
\Sigma-3 P-2 s .-N P T\end{array}$ & $\begin{array}{l}c e k-u-n a-n \\
\sum-3 \mathrm{P}-2 \mathrm{~s} . \mathrm{PT}\end{array}$ \\
\hline & $\begin{array}{l}m a-c e ? \\
\text { NEG- } \Sigma\end{array}$ & 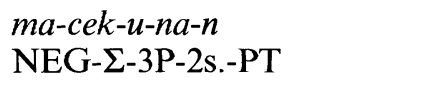 \\
\hline \multirow[t]{2}{*}{$2 \mathrm{pl} . \rightarrow 3$} & $\begin{array}{l}c e P-n-u-d u \\
\sum-2 \text { pl.-3P-NPT }\end{array}$ & $\begin{array}{l}c e P-n-u-n \\
\Sigma-2 \text { pl.-3P-PT }\end{array}$ \\
\hline & $\begin{array}{l}m a-c e ? \\
\text { NEG- } \Sigma\end{array}$ & $\begin{array}{l}\text { ma-ceP-n-u-n } \\
\text { NEG- } \Sigma-2 \text { pl.-3P-PT }\end{array}$ \\
\hline \multirow[t]{2}{*}{$3 \mathrm{~s} . \rightarrow 2 \mathrm{~s}$} & $\begin{array}{l}c e P-\emptyset-n a-d u \\
\Sigma \text {-s.AS-2s.-NPT }\end{array}$ & $\begin{array}{l}c e P-\emptyset-n a-n \\
\Sigma \text {-s.AS-2s.-PT }\end{array}$ \\
\hline & $\begin{array}{l}m a-c e ? \\
\text { NEG- } \Sigma\end{array}$ & $\begin{array}{l}\text { ma-ce?-Ø-na-n } \\
\text { NEG- } \Sigma-\text {-s.AS-2s.-PT }\end{array}$ \\
\hline
\end{tabular}


TABLE 4 (continued)

\begin{tabular}{|c|c|c|}
\hline \multirow[t]{2}{*}{$3 \mathrm{pl} . \rightarrow 2 \mathrm{~s}$} & $\begin{array}{l}\text { ceP-yon-na-du } \\
\Sigma \text {-pl.AS-2s.-NPT }\end{array}$ & $\begin{array}{l}\text { ceP-yon-na-n } \\
\Sigma \text {-pl.AS-2s.-PT }\end{array}$ \\
\hline & $\begin{array}{l}m a-c e ? \\
\text { NEG- } \Sigma\end{array}$ & $\begin{array}{l}\text { ma-ceP-yon-na-n } \\
\text { NEG- } \Sigma \text {-pl.AS-2s.-PT }\end{array}$ \\
\hline \multirow[t]{2}{*}{$3 \rightarrow 2 \mathrm{pl}$} & $\begin{array}{l}c e P-n i-d u \\
\Sigma \text {-2pl.-NPT }\end{array}$ & $\begin{array}{l}c e \text { P-ni-n } \\
\Sigma-2 \text { pl.-PT }\end{array}$ \\
\hline & $\begin{array}{l}m a-c e ? \\
\text { NEG- } \Sigma\end{array}$ & $\begin{array}{l}m a-c e P-n i-n \\
\text { NEG- } \Sigma-2 \text { pl.-PT }\end{array}$ \\
\hline \multirow[t]{2}{*}{ 3s. $\rightarrow 3$} & $\begin{array}{l}c e k-\emptyset-u-d u \\
\Sigma \text {-s.AS-3P-NPT }\end{array}$ & $\begin{array}{l}\text { cek-Ø-u-no } \\
\Sigma \text {-s.AS-3P-3 } \rightarrow 3 / \mathrm{PT}\end{array}$ \\
\hline & $\begin{array}{l}m a-c e ? \\
\text { NEG- } \Sigma\end{array}$ & $\begin{array}{l}m a-c e k-\emptyset-u-n s \\
\text { NEG- } \Sigma \text {-s.AS-3P-3 } \rightarrow 3 / \mathrm{PT}\end{array}$ \\
\hline \multirow[t]{2}{*}{$3 \mathrm{pl} . \rightarrow 3$} & $\begin{array}{l}c e P-y o \eta-d u \\
\Sigma \text {-pl.AS-NPT }\end{array}$ & $\begin{array}{l}\text { ceP-yon-no } \\
\Sigma \text {-pl.AS-3 } \rightarrow 3 / \mathrm{PT}\end{array}$ \\
\hline & $\begin{array}{l}m a-c e ? \\
\text { NEG- } \Sigma\end{array}$ & $\begin{array}{l}\text { ma-ceP-yon-ns } \\
\text { NEG- } \sum \text {-pl.AS-3 } \rightarrow 3 / \mathrm{PT}\end{array}$ \\
\hline
\end{tabular}

\section{Proto-Kiranti}

Previous comparisons of Kiranti verbal agreement systems (van Driem, 1990, 1991a, 1991b, 1997) show the conjugations of Kiranti verbs to reflect a splitergative pattern in which third person actants are marked differently in the verb than are first and second person actants (van Driem, 1991b: 346). To elaborate briefly, in Kiranti languages morphemes indicating involvement of a third person actant usually reflect a so-called accusative system in which separate sets of morphemes index for a third person patient (3P) as opposed to a third person agent or subject (3AS). On the other hand, morphemes denoting the involvement of a first or second person actant follow an ergative pattern in that one set of morphemes indexes for first or second person agent (12A) while another set denotes first or second person patient or subject (12PS). Moreover, number of actant has been seen to be 'indexed in the verb by different but apparently cognate morphemes for third person versus first and second person actants' (ibid., 346). As the morphemic analysis of the Thangmi verbal agreement system demonstrates, Thangmi conforms to the Kiranti splitergativity model in structure while it differs in the specifics.

Where in Kiranti languages the marking of first and second person follows an ergative pattern and the marking of third person actants in the verb follows an accusative pattern, in Thangmi it is only the first person which is marked ergatively by verbal agreement suffixes and the non-first person, i.e. second and third person, shows the accusative pattern. The endings filling the second functional position, suffixal slot 2, in the Thangmi affixal string offer an insight into the particular pattern of split ergativity in this language. The ending $<-w a>$ marks first person plural agent (1pl.A), while the ending $<-i \sim-P i>$ denotes first person plural patient or subject (1pl.PS), both reflecting an ergative agreement pattern. On the other hand, the zero morpheme marking singular number (s.AS) of a non-first person agent or subject, and the number suffix $<-y o \eta>$ marking plural number of a non-first person agent or subject 
(pl.AS), show the accusative pattern. This accusative pattern is also reflected in Thangmi by the third person patient the morpheme $<-u>(3 \mathrm{P})$ in suffixal slot 4 . As the analysis demonstrates, Thangmi clearly exhibits a pattern of split ergativity, similar but essentially different to that of the Kiranti type. In connection with this discussion, it is worthy of note that the Thangmi conjugation exhibits a significant level of morphological fusion reflected by a disproportionately large number of portmanteau suffixes, i.e. four out of fifteen.

In the remainder of this article, I will compare and contrast the Thangmi verbal agreement system with the Proto-Kiranti model as developed by the comparison of the conjugational morphologies of Bahing, Dumi, Hayu, Kulung, Limbu, Lohorung and Thulung verbs. The most recent model, proposed in van Driem (1991b: 354, cf. 1997), is given below in Table 5. The following discussion deals solely with Thangmi verbal morphology in as much as it relates to and reflects the Proto-Kiranti model. For a full discussion of all the comparative conjugational morphologies of Kiranti languages and an analysis, see van Driem (1990, 1991a and 1991b, 1997).

TABLE 5: The Proto-Kiranti verbal agreement system

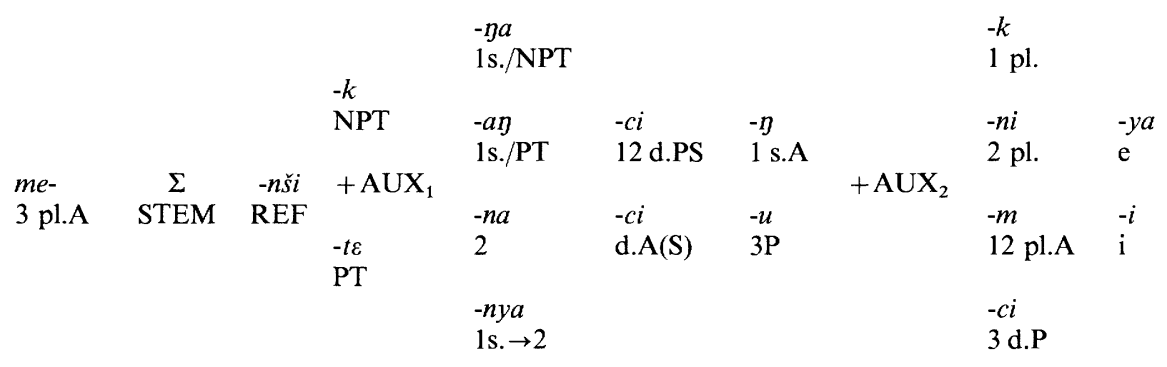

First, I shall deal with the morphemes in Thangmi which have clear ProtoKiranti, and often even Proto-Tibeto-Burman, cognates. The Thangmi negative morpheme $<m a->$ (NEG) is cognate with the Limbu and Dumi negative prefixes $<m \varepsilon->$ and $\langle m \ni->$, respectively, although un-tensed negative prefixes are by no means common to all Kiranti languages. Tables 6 to 9 show Thangmi reflexes which are identical to their Proto-Kiranti cognates and require little explanation. In those Kiranti languages where a reflexive morpheme is attested, these reflexes of the Proto-Kiranti reflexive suffix $*<-n s ̌ i>$ (REF) are suffixed immediately to the stem, preceding any other morphemes.

TABLE 6: Reflexes of the Proto-Kiranti reflexive suffix $*<-n s ̌ i>(R E F)$

$\begin{array}{lllr}\text { Proto-Kiranti } & *<-n s ̌ i & \text { REF } & * \text { sf.1 } \\ \text { Limbu } & <-s i \eta,-n \varepsilon> & \text { REF } & \text { sf.1 } \\ \text { Dumi } & <-n s i,-s i> & \text { REF } & \text { sf.1 } \\ \text { Hayu } & <-n a \sim-n t s e \sim-n t s i> & \text { REF } & \text { sf.1 } \\ \text { Bahing } & <-s i> & \text { REF } & \text { sf.1 } \\ \text { Thangmi } & <-\int i> & \text { REF } & \text { sf.1 }\end{array}$

Some of the reflexes of the Proto-Kiranti second person morpheme $*<-n a>$ are listed in Table 7, reflexes of the Proto-Kiranti third person patient morpheme $*<-u>$ are provided in Table 8 , and reflexes of the Proto-Kiranti second person plural morpheme ${ }^{*}<-n i>$ are given in Table 9. 
TABLE 7: Reflexes of the Proto-Kiranti second person morpheme * $<-n a>$

$\begin{array}{lccc}\text { Proto-Kiranti } & *<-n a> & 2 & *_{\text {sf.3 }} \\ \text { Thulung } & <-n a> & 2 & \text { sf.1 } \\ \text { Lohorung } & <-n a> & 2 & \text { sf.7 } \\ \text { Thangmi } & <-n a> & \text { 2s. } & \text { sf.4 }\end{array}$

TABLE 8: Reflexes of the Proto-Kiranti third person patient morpheme ${ }^{*}<-u>$

$\begin{array}{lllr}\text { Proto-Kiranti } & *<-u> & 3 \mathrm{P} & * \text { sf.5 } \\ \text { Lohorung } & <-u> & 3 \mathrm{P} & \text { sf.4 } \\ \text { Kulung } & <-o \sim-2 \sim-u> & 3 \mathrm{P} & \text { sf.4 } \\ \text { Limbu } & <-u> & 3 \mathrm{pl} & \text { sf.4 } \\ \text { Thangmi } & <-u> & \text { 3P } & \text { sf.3 }\end{array}$

TABLE 9: Reflexes of the Proto-Kiranti second person plural morpheme *<-ni>

$\begin{array}{llll}\text { Proto-Kiranti } & *<-n i> & 2 \mathrm{pl} . & *_{\text {sf.7 }} \\ \text { Thulung } & <-n i> & 2 \mathrm{pl} . & \text { sf.1 } \\ \text { Lohorung } & <-n i> & 2 \mathrm{pl} . & \text { sf.7 } \\ \text { Kulung } & <-n i> & 2 \mathrm{pl} . & \text { sf.3 } \\ \text { Bahing } & <-n i> & 2 \mathrm{pl} . & \text { sf.6 } \\ \text { Thangmi } & <-n i \sim-n> & \mathbf{2 p l} . & \text { sf.2 }\end{array}$

Tables 10 to 12 show reflexes in Thangmi that are close, although not identical, to Kiranti proto-morphemes. It is clear that in Kiranti languages, as well as in the Tibeto-Burman family in general, the presence of a velar nasal $/ \boldsymbol{g} /$ indicates the involvement of a first person singular actant. As van Driem suggests, ' most first-singular morphemes in modern Kiranti languages consist of the velar nasal $/ \boldsymbol{y} /$ with some associated vowel preceding or following the nasal' (1991b: 350). The Thangmi first person singular actant morpheme $<-\eta a\rangle$ (1s.) is seen to be a reflex of either, or both, of the Proto-Kiranti morphemes $*<-\eta\rangle$, which indexes first person singular agent (1s.A), and $*<-\eta a>$, which marks first person singular actant in non-preterite time (1s./NPT).

TABLE 10: Reflexes of Proto-Kiranti first person morphemes

$$
\left.\begin{array}{l}
\begin{array}{l}
\text { Proto-Kiranti } \\
*<-\eta>1 \mathrm{~s} . \mathrm{A} \\
*<-\eta a>1 \mathrm{~s} . / \mathrm{NPT}
\end{array}
\end{array}\right\} \quad \begin{aligned}
& \text { Thangmi } \\
& <-\eta a>1 \mathrm{~s} .
\end{aligned}
$$

$\begin{array}{lclr}\text { Proto-Kiranti } & *<-\eta> & 1 \text { s.A } & * \text { sf.5 } \\ \text { Proto-Kiranti } & *<-\eta a> & 1 \text { s./NPT } & *_{\text {sf.3 }} \\ \text { Limbu } & <-\eta> & 1 \text { s.A } & \text { sf.5 } \\ \text { Lohorung } & <-n> & 1 \text { s.A } & \text { sf.5 } \\ \text { Lohorung } & <-\eta a> & 1 \text { s. } & \text { sf.2 } \\ \text { Dumi } & <-\eta> & 1 \text { s. } & \text { sf.2 } \\ \text { Thangmi } & <-\eta \boldsymbol{a}> & \text { is. } & \text { sf.5 }\end{array}$

The Thangmi tensed portmanteau morpheme $<-u \eta\rangle$, marking the transitive relationship between a first person singular agent and a third person patient in preterite time, is very Kiranti indeed. In fact, the Thangmi tensed portmanteau morpheme $<-u \eta\rangle$ could be seen as a fusion of the Proto-Kiranti 
morpheme ${ }^{*}<-u>$ denoting third person patient (3P) with the protomorpheme $*<-a \eta>$ denoting first person singular actant in preterite time (1s./PT). If this analysis is accepted, it would seem that, with regard to the portmanteau morpheme $\langle-u \eta\rangle$ at least, Thangmi is a living example of the Proto-Kiranti model and more canonically Kiranti in morphological structure than some extant Kiranti languages.

TABLE 11: Reflexes of Proto-Kiranti first person actant and third person patient morphemes

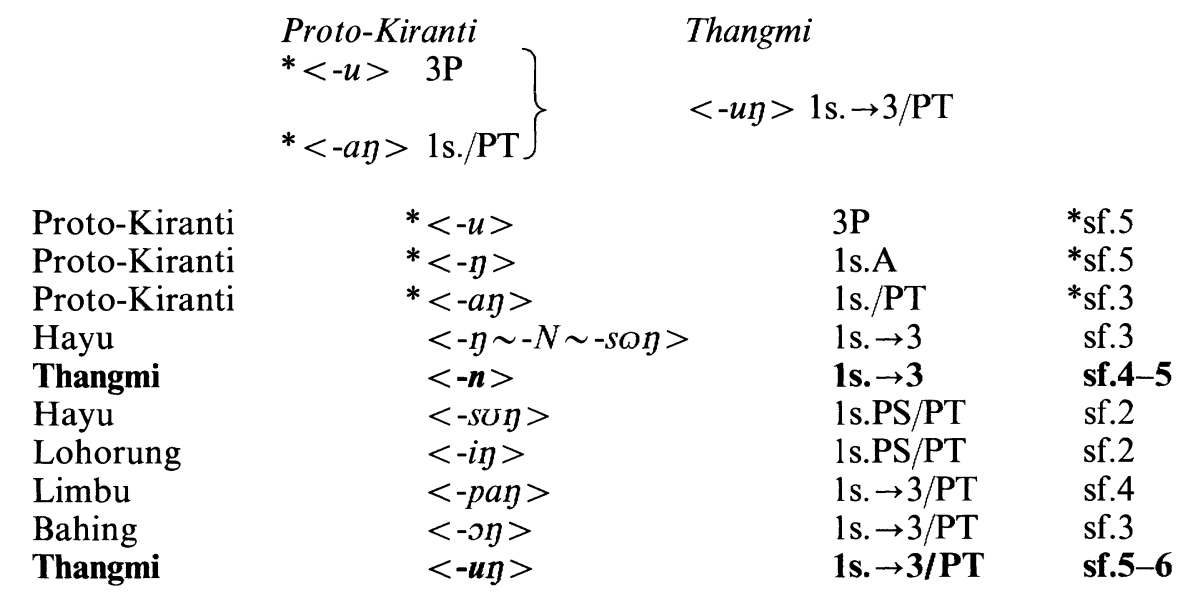

The Thangmi morpheme $<-i \sim-P i>$, denoting first person plural patient or subject (1pl.PS), seems to be a reflex of the Proto-Kiranti inclusive suffix $*<-i>$. Thangmi makes no inclusive-exclusive distinction, and it is therefore unsurprising that the reflex of the Proto-Kiranti inclusive marker indexes the involvement of a plural first person in a given scenario, especially since both first person and plural number are implicit in any inclusive category. Moreover, when the Thangmi reflex is shown alongside reflexes of this proto-morpheme in other Kiranti languages, it becomes clear that the above extrapolation is perfectly in accordance with the data. In Lohorung, for example, the reflex of the Proto-Kiranti inclusive suffix $*<-i>$ also denotes first person plural patient or subject (1pl.PS).

TABLE 12: Reflexes of the Proto-Kiranti inclusive suffix $*<-i>$

$\begin{array}{llll}\text { Proto-Kiranti } & *<-i> & \text { inclusive } & *_{\text {sf.8 }} \\ \text { Limbu } & <-i> & \text { pPS } & \text { sf.4 } \\ \text { Thulung } & <-i> & 1 \text { pl.i } \rightarrow 3 & \text { sf.7 } \\ \text { Lohorung } & <-i> & \text { 1pl.PS } & \text { sf.3 } \\ \text { Thangmi } & <-i \sim-P i> & \text { 1pl.PS } & \text { sf.2-5 }\end{array}$

Where the above examples and tables 6 through 12 show Thangmi to resemble both the Proto-Kiranti model as well as extant Kiranti languages, the following tables demonstrate the limits of this comparison. Table 13 shows Proto-Kiranti morphemes alongside their Thangmi counterparts which, despite indexing for a similar meaning, take a very different form and often occupy a different functional position in the affixal string. 
TABLE 13: Thangmi endings unrelated to their Kiranti counterparts

Proto-Kiranti

\begin{tabular}{|c|c|c|c|c|c|}
\hline$*<-k>$ & NPT & $*_{\mathrm{sf} .2}$ & $\neq$ & $<-d u>$ & NPT \\
\hline$*<-t \varepsilon>$ & PT & ${ }^{*} \mathrm{sf} .2$ & $\neq$ & $<-n>$ & PT \\
\hline$*<-k>$ & $1 \mathrm{pl}$. & $*_{\mathrm{sf} .7}$ & & & \\
\hline$*<-m>$ & 12pl.A & ${ }^{*}$ sf.7 & $\neq$ & $<-w a>$ & 1pl.A \\
\hline
\end{tabular}

It is also highly relevant that the functional order of the Proto-Kiranti suffixes shown in table 13 seems to be reversed in Thangmi. Where the tense markers occupy an early suffixal position in Proto-Kiranti, they occupy a late slot in the affixal chain of Thangmi. Likewise, where the plural person morphemes occupy a late functional position in Proto-Kiranti, the first person plural agent morpheme $<-w a>(1 \mathrm{pl} . \mathrm{A})$ in Thangmi occurs early on in the string, in suffixal slot 2. However, reflexes from other Kiranti languages sometimes resemble cognate Thangmi morphemes when a simple comparison between the Proto-Kiranti model and the Thangmi reflex would obscure this hypothetical link. For example, the Hayu reflex of the Proto-Kiranti preterite tense morpheme ${ }^{*}<-t \varepsilon>$, also denoting preterite tense, has been transcribed as $\langle-N\rangle$ by Michailovsky (1988), and resembles, at least in form (although not in its functional position), the Thangmi reflex denoting preterite time $<-n\rangle$ (PT). On the other hand, the Thangmi marker $<-d u>$, denoting non-preterite tense in each and every verbal scenario, seems to be cognate with the Dzongkha copula 25 प $(h d u g)<d \hat{u} \sim d u>$, rather than with anything Proto-Kiranti.

Table 14 shows the morphemes for Proto-Kiranti, as reconstructed by van Driem (1991b: 354), for which there are no reflexes in Thangmi.

TABle 14: Proto-Kiranti morphemes without Thangmi counterparts

$\begin{array}{lll}*<-m e> & 3 \text { pl.A } & { }_{\text {pfx }} \\ *<-n y a> & 1 \mathrm{~s} . \rightarrow 2 & *_{\mathrm{sf} .3} \\ *<-c i> & \text { d.A(S) } & *_{\mathrm{sf} .4} \\ *<-c i> & 3 \mathrm{~d} . \mathrm{P} & *_{\mathrm{sf} .7} \\ *<-y a> & \text { exclusive } & *_{\mathrm{sf} .8}\end{array}$

In the case of three of the five proto-morphemes shown, viz. ${ }^{*}<-c i>$ (d.A(S)), ${ }^{*}<-c i>$ (3d.P) and ${ }^{*}<-y a>$ (exclusive), the categories that they mark are lacking in Thangmi altogether. In short, these categories are not marked by other, non-cognate, morphemes in the Thangmi affixal string, but rather not marked at all, the point being that since Thangmi has no specific dual category, it follows that Thangmi will have no morphemes to mark dual agent or subject (d.AS) or third person dual patient (3d.P). Furthermore, there is no specific third person plural agent ( $3 \mathrm{pl} . \mathrm{A})$ category in Thangmi. There is only a plural agent or subject non-first person (pl.AS) category, marked by the Thangmi morpheme $\langle-y o y\rangle$.

Although Thangmi, in common with Kiranti languages, has a relatively large number of fused, unsegmentable portmanteau morphemes which express the nature of both actants in a transitive relationship and sometimes also tense, some scenarios are indexed by two separate suffixes in Thangmi where they are encoded by a single portmanteau morpheme in Proto-Kiranti. The most conspicuous example of this is the transitive relationship between a first person singular agent and a second person patient $(1 \mathrm{~s} . \rightarrow 2)$, marked by the morpheme * <-nya $>$ in Proto-Kiranti, which in Thangmi is encoded by two separate 
suffixes, one denoting the first person singular actant and the other marking the involvement of a second person.

\section{Conclusion: the Mahākirāntī hypothesis}

The weight that should be given to studies of comparative conjugational morphology as an index of the degree of genetic relationship between TibetoBurman languages is an oft-debated and moot point. As Scott DeLancey has noted, even the earliest work on Tibeto-Burman languages by Grierson and Konow 'utilized the presence or absence of agreement marking on the verb as a primary criterion for classification' (1989: 315). Van Driem, although acknowledging that verbal morphology constitutes only 'one type of evidence which has yet to be corroborated by regular lexical and phonological correspondences', sees inflexional comparison as providing evidence of a 'highly sound and compelling kind' (1992: 246). LaPolla, on the other hand, is cautious of what he calls ' paradigm stuffing' and suggests that in our zest for reconstruction, we 'should not build up morphological systems' (1992: 312). It is pertinent to point out that according to conventional wisdom in historical linguistics flexional morphology is considered to be the heart of the inherited portion of the language, and genetic relationships between Indo-European languages had been firmly established on morphological grounds long before the sound laws had been discovered.

In this article, I have concentrated solely on the verbal morphology of Thangmi, both synchronically for the purpose of describing a hitherto largely undocumented language, and diachronically for exploratory comparison with the Proto-Kiranti model. It appears that Thangmi occupies a half-way house between a canonical Kiranti-style verbal agreement system and that of the less inflecting Tibeto-Burman languages. Quite where this leaves Thangmi in terms of its genetic affiliation is unclear. It may well form part of the Eastern Himalayan grouping, which includes 'the Kiranti languages and others in eastern Nepal; probably also Newari' (Delancey, 1989: 321), but by the same token, it could perhaps be better grouped under the tentative heading of Mahākirāntī, a 'hypothetical genetic unit' proposed by van Driem to include Kiranti and Newar (1992: 246). It is perhaps fitting to point out at this juncture that, as explained in van Driem (1993b) and reiterated time and time again by spokesmen of the Newar academic community, the term of choice in English for both the indigenous people and language of the Kathmandu valley is 'Newar', and emphatically not the Aryan-inspired term 'Newari', which is felt to be offensive to contemporary Newar sensibilities. The argument for classifying Thangmi in the Mahākirāntī group is as follows.

Van Driem contends that there is a Kiranti-Newar genetic link, an argument supported by Carol Genetti's Dolakhā Newar data as well as Jørgensen's studies of Classical Newar, and suggests that this higher-level grouping may be called Mahākirāntī. Conjugational affixes of the Dolakhā dialect of Newar can be easily traced to their cognate morphemes in other Tibeto-Burman verbal agreement systems, but the specific presence of the morpheme $<-u>$, indexing third person future (3/FUT), most probably a reflex of the Proto-Kiranti morpheme $*<-u>$ denoting third person patient involvement (3P), is of considerable significance. As van Driem suggests elsewhere:

The third person proto-morpheme ${ }^{*}<-u>$ is ubiquitously reflected in

Tibeto-Burman ... In the Himalayas, these reflexes are all suffixes, and, in

Kiranti languages, they all denote third person patient involvement. The

Dolakha data likewise reflect third person patient marking: The vestigial 
suffix $\langle-u\rangle$ in the negative indicative, singular imperative and singular optative of r-stem verbs is clearly associated with grammatical patient marking, as it occurs only after transitive verbs. Similarly, in the past indicative, third singular subject is indexed by the suffix $\langle-a\rangle$ in intransitive verbs, but by $\langle-u\rangle$ in transitive verbs. (1993b: 36-37)

As we have seen, the Thangmi reflex of this proto-morpheme is also a suffix, $\langle-u\rangle$, and this suffix marks quite specifically third person patient. Much of the above evidence points to a greater genetic affinity between Kiranti and Thangmi, and thereby also to Newar, and the probability of finding regular lexical and phonological correspondences between Kiranti and Thangmi seems high. For example, the Tibeto-Burman reflex for 'meat' has undergone the same semantic evolution in Thangmi, Barām and Newar, and has come to mean specifically 'cow' in all three languages: Thangmi $\int a$, Barām sya (van Driem, forthcoming), and Newar sā (Genetti, 1994: 51). In her discussion of the evidence for a special Kiranti-Rung relationship, Karen Ebert says in mitigation, 'It is surely premature to claim a new classification only on the basis of verbal paradigms, although they must, due to their conservatism, play a role in any classification' (1990: 76-77). Although the evidence adduced thus far for a close genetic affinity between Kiranti and Rung is still ambiguous, analyses of the morphology of the verbal agreement systems, such as the one provided here for Thangmi, do seem to support the Mahäkirāntī hypothesis. The pivotal importance of comparative morphology to historical linguistics has been properly appreciated by Indo-European scholars for over two hundred years. The exact relationship of Thangmi to the Kiranti languages in other respects will be determined by further study.

\section{REFERENCES}

Benedict, Paul King. 1972. Sino-Tibetan, a conspectus. Cambridge: Cambridge University Press. DeLancey, Scott. 1989. 'Verb agreement in Proto-Tibeto-Burman', BSOAS, 52/2: 315-33.

Driem, George van. 1990. 'An exploration of Proto-Kiranti verbal morphology', Acta Linguistica Hafniensa, 22/2: 27-48.

Driem, George van. 1991a. 'Le proto-kiranti revisité, morphologie verbale du lohorung', Acta Linguistica Hafniensa, 24: 33-75.

Driem, George van. 1991b. 'Bahing and the Proto-Kiranti verb', BSOAS, 54/2: 336-56.

Driem, George van. 1992. 'In Quest of Mahākirāntī', Contributions to Nepalese Studies-Journal of the Centre of Nepal and Asian Studies of Tribuvan University, 19/2: 241-7.

Driem, George van. 1993a. 'The Proto-Tibeto-Burman verbal agreement system', BSOAS, 56/2: $292-334$.

Driem, George van. 1993b. 'The Newar verb in Tibeto-Burman perspective', Acta Linguistica Hafniensa 26: 23-43.

Driem, George van. 1997. 'A new analysis of the Limbu verb', Tibeto-Burman Languages of the Himalayas (Papers in Southeast Asian Linguistics No. 14), Canberra: Pacific Linguistics, 157-73.

Driem, George van. (forthcoming) The Barām Language.

Ebert, Karen. 1990. 'On the evidence for the relationship Kiranti-Rung', Linguistics of the TibetoBurman Area, 13/1: 57-77.

Genetti, Carol Elaine. 1994. A descriptive and historical account of the Dolakha Newari dialect (Monumenta Serindica no. 24.) Tokyo: Institute for the Study of Languages and Cultures of Asia and Africa.

Jørgensen, Hans. 1936. 'Linguistic remarks on the verb in Newārī', Acta Orientalia, XIv, Leiden: E.J. Brill, 280-5.

Grierson, George Abraham (ed.). 1909. Linguistic survey of India. Calcutta: Superintendent of Government Printing.

LaPolla, Randy J. 1992. 'On the dating and nature of verb agreement in Tibeto-Burman', BSOAS, 55/2: 298-315.

Loeffen, Adriaan Isodorus Franciscus 'Arno'. 1995. 'The Bhrámú language of central Nepal'. Unpublished MA thesis, Leiden University.

Michailovsky, Boyd. 1988. La langue hayu. Paris: Editions du Centre National de la Recherche Scientifique.

Rutgers, Roland. 1993. 'The Chepang verb', Acta Linguistica Hafniensa, 26: 107-37.

Shafer, Robert. 1966. Introduction to Sino-Tibetan. Wiesbaden: Otto Harrassowitz. 